Annales Missiologici Posnanienses t. 24 (2019), s. 7-30

doi: 10.14746/amp.2019.24.1

ORCID: 0000-0002-8765-1855

TOMASZ SZYSZKA

Uniwersytet Kardynała Stefana Wyszyńskiego w Warszawie

Wydział Teologiczny

\title{
Zarys historii ewangelizacji Meksyku od XVI do XVII wieku
}

Historia ewangelizacji Nowej Hiszpanii okresu kolonialnego jest niezwykle bogata we frapującą i wielopłaszczyznową sekwencję różnorodnych wydarzeń. Misjonarze, którzy przybyli na ziemie azteckie w trzeciej dekadzie XVI w., zostali skonfrontowani z wieloma nowymi wyzwaniami, z jakimi nie mieli do czynienia w basenie Morza Karaibskiego w poprzednich trzech dekadach. Konkwista imperium azteckiego, dokonana przez grupę Hiszpanów pod wodzą Hernána Cortésa w latach dwudziestych XVI w., stworzyła bowiem możliwości pracy ewangelizacyjnej na nowym obszarze. Wysoko rozwinięta kultura aztecka, w tym rozmaite formy religijności autochtonicznej, były dla Europejczyków wielkim zaskoczeniem, ponieważ do tej pory na Karaibach mieli oni do czynienia jedynie z ludami o raczej niskim poziomie kultury materialnej i duchowej. Tym samym misjonarze stanęli przed trudnym zadaniem, jakim było wypracowanie i zastosowanie nowych, odmiennych form i metod pracy misyjnej.

Celem niniejszego artykułu, syntetycznie przedstawiającego ewangelizację Meksyku w XVI i XVII w., jest próba podważenia powszechnie powielanej opinii, że Meksyk w wieku XVI to tylko krwawa konkwista, oraz przeświadczenia, że ewangelizacja polegała jedynie na legitymizowaniu nieetycznych dążeń Korony Hiszpańskiej. To właśnie głównie zakonnicy, jako jedni z nielicznych, piętnowali naganne zachowania Hiszpanów.

Misyjny zapał zakonników był wystarczającym motywem do podejmowania trudu nauki języków i opracowywania pomocy katechetycznych, liturgicznych oraz homiletycznych w językach indiańskich. Skłaniał misjonarzy do zakładania wiosek misyjnych, w tym pueblos-hospitales, czy też do prowadzenia szkół i zajmowania się edukacją, krzewienia nowych form pracy na roli i stosowania nowych technologii (Galmés 615-622). Wysiłki ewangelizacyjne 
obejmowały również takie zakresy jak: architekturę, sztukę, muzykę, medycynę, geografię, kartografię, etnografię itd. Stąd też trafna wydaje się myśl Andrzeja Dembicza, że należałoby zwrócić uwagę na „ogromną intensywność produkcji intelektualnej”, przypadającą na ten okres, oraz na „teksty, które wprawdzie nie zrywały całkowicie $\mathrm{z}$ tradycją dotychczasowego interpretowania świata, ale które budowały jego nową wizję" (Dembicz 62).

Spoglądając na zaangażowanie misyjne i ewangelizacyjne misjonarzy franciszkańskich, dominikańskich, jezuickich oraz innych, trudno nie zauważyć, że ich działalność zawsze była wielopłaszczyznowa (Velásquez García 295-296). Przygotowywali Indian do przyjęcia wiary chrześcijańskiej, a w konsekwencji do życia opartego na zasadach wiary i kultury chrześcijańskiej. Nie chodziło jednak wyłącznie o zbawienie dusz w wymiarze duchowym. Już wówczas podejmowano bowiem efektywne próby realizacji tego, co współcześnie określane jest jako promocja ludzka lub ewangelizacja integracyjna.

\section{Kontekst polityczno-społeczny początków ewangelizacji Meksyku}

Podbój Imperium Azteckiego, dokonany przez hiszpańskich konkwistadorów w latach dwudziestych XVI w., oznaczał siłowe podporządkowanie tych ziem interesom Korony Hiszpańskiej. Po bitwie o Tlaxcala (przeciwko Xicohténcatl) w 1519 r. i po innych licznych potyczkach oraz zdobyciu miasta Tenochtitlán, w tym pojmaniu władcy Montezumy II, Hiszpanie przystąpili do umacniania swojego panowania na owym obszarze. Tym samym tamtejsze ludy, współtworzące dotychczasowe Trójprzymierze Azteckie, zmuszone zostały do zaakceptowania nowego porządku społeczno-kulturowego według wzorców hiszpańskich (Grzybowski 15-16; Coe 84-150).

Na przestrzeni kilku dekad Hiszpanie zdołali nie tylko podbić ten olbrzymi obszar, ale i położyć fundamenty pod struktury administracji państwowej i kościelnej (Milhou 784-786, 781-792; Morales Valerio 1992d, 92-95; Alvear Acevedo 79-81). W 1535 r. powstało wicekrólestwo Nowej Hiszpanii z siedzibą w mieście Meksyk, które w następnych dekadach podlegało kolejnym zmianom administracyjnym (Velásquez García 270-271). Pierwsza archidiecezja na tym obszarze została powołana do życia w 1547 r., co w praktyce oznaczało usamodzielnienie się istniejących w Ameryce Środkowej diecezji od metropolii w Sewilli. Funkcjonowały już bowiem na tym obszarze diecezje z siedzibą w Tlaxcala (1525), mieście Meksyk (1526, od 1547 archidiecezja), Oaxaca (1535), Michoacán (1536) i Chiapas (1539). Nieco później powstały diecezje w Guadalajara (1548) i na Jukatanie (1561). We wszystkich ośrodkach miejskich, w których mieszkała ludność pochodzenia hiszpańskiego, funkcjonowały parafie, natomiast na obszarach zasiedlanych przez ludność 
autochtoniczną dzieło chrystianizacji było realizowane na bazie doctrinas oraz wiosek misyjnych, które z biegiem czasu przekształcano w parafie. Pod koniec XVI w. w Meksyku funkcjonowały 474 parafie.

Tak szybki rozwój struktur kościelnych był możliwy dzięki polityce Korony Hiszpańskiej, w myśl której konsekwentne rozwijanie struktur administracyjnych w Nowym Świecie miało na celu nie tylko podbicie tych ziem, ale również programowe ich zagospodarowanie. Istotnym impulsem stała się bulla papieska Exponi nobis z 1522 r., ponieważ wydatnie motywowała Koronę Hiszpańską do dynamicznego współtworzenia struktur kościelnych w Meksyku. Stąd też Korona, zgodnie z zasadami patronatu królewskiego, poczuwała się do obowiązku prowadzenia działalności misyjnej i tworzenia struktur kościelnych na odkrywanych ziemiach, aczkolwiek realizacja tego zadania była w znacznym stopniu podporządkowana interesom Korony (Velásquez García 216-217). Fundusze przeznaczone na dzieło chrystianizacji Nowej Hiszpanii pozwalały na wysyłanie z Europy coraz większej liczby zakonników (franciszkanów, dominikanów, augustianów, jezuitów) i zakładanie klasztorów, ośrodków misyjnych, których celem było nawracanie Indian oraz ich dalsza ewangelizacja. Jednak misjonarze skierowani do pracy w Nowym Świecie, mający jak najbardziej motywację religijną (pełnienie woli Boga, wprowadzanie Bożego porządku, głoszenie Słowa Bożego itd.), byli nosicielami ówczesnej europejskiej myśli teologicznej. Jednocześnie pozostawali świadomi tego, że są zobowiązani do wypełniania zadań wskazywanych przez administrację Korony Hiszpańskiej.

Podporządkowywane w XVI w. władzy Korony kolejne obszary Nowej Hiszpanii stawały się dla misjonarzy terenami, które należało zagospodarować, wprowadzając nowe prawa i zwyczaje oraz europejskie normy i chrześcijańskie tradycje. Tym samym misjonarze musieli sprostać trudnemu zadaniu, jakim była adekwatna realizacja polityki Korony oraz właściwe zastosowanie norm nauczania kościelnego, przy jednoczesnym uwzględnieniu nowości płynących z nowego kontekstu społeczno-kulturowego. Jednym z poważnych, ówczesnych dylematów misjonarzy była kwestia tzw. wojny sprawiedliwej, czyli możliwości jakoby zgodnego z prawem zmuszania Indian przez Hiszpanów do niewolniczej pracy w kopalniach i na plantacjach. Pejoratywne określenia Indian z tamtego okresu (barbarzyńcy, poganie, bezbożni, bezrozumni, nierozgarnięci, prymitywni itd.), używane w oficjalnych dokumentach i listach wysyłanych do Hiszpanii, miały na celu ich całkowite zdyskredytowanie w oczach króla i urzędników królewskich, aby tym samym można było usprawiedliwić własne, nieetyczne i niezgodne z ówczesnym prawem postępowanie. Tak agresywna i nieprzejednana postawa Hiszpanów wobec społeczności indiańskich w Meksyku skutkowała bezwzględnością Indian broniących własnej godności i swoich posiadłości (Mendieta 39-48). Kościół nie był jedynie 
biernym obserwatorem wydarzeń, ale poszukiwał środków, by zwrócić uwagę na aspekt etyczny. Misjonarze stawiali sobie bowiem pytanie, jak ewangelizować oraz jak nie dopuścić do szerzenia się niesprawiedliwości społecznej w odniesieniu do ludności autochtonicznej (Bey 121-124).

$\mathrm{Na}$ uwagę w tym kontekście zasługują niektórzy ordynariusze z Nowej Hiszpanii z pierwszej połowy XVI w. Dominikanin Julián Garcés, który pracował w Meksyku od roku 1527, został pierwszym biskupem w Oaxaca. To właśnie on, widząc niesprawiedliwe traktowanie Indian, naciskał na papieża Pawła III, aby ten wydał dokument regulujący kwestię wolności Indian. Jego starania zaowocowały ogłoszeniem w roku 1537 bulli Sublimis Deus. Innym znanym biskupem był franciszkanin Juan de Zumárraga (1528-1548) z Meksyku, związany nie tylko z wydarzeniami w Guadalupe w 1531 r., ale też z kwestiami czynnej ochrony Indian (Bey 124-133, 136-141; Gómez Canedo 246-250; Chávez 2010, 59-63), założeniem uniwersytetu, sprowadzeniem pierwszej drukarni do Nowego Świata czy też otwarciem szkoły dla indiańskich dziewcząt (Martín Rivera 108-110; Alvear Acevedo 132-134). Kolejnym wybitnym biskupem był dominikanin Bartolomé de las Casas z Chiapas, który sakrę biskupią otrzymał w roku 1543. W swoim dziele, zatytułowanym $D e$ unico vocationis modo omnium gentium ad veram religionem (1537), zaprezentował pogląd na metody działalności misyjnej, podkreślając jej pokojowy charakter. Był tak mocno zaangażowany w ochronę i obronę Indian, że po trzech miesiącach przebywania w diecezji zmuszony został przez tamtejszych konkwistadorów i właścicieli ziemskich do jej opuszczenia.

Fundusze z patronatu królewskiego umożliwiały też budowę wielkich i bogato wyposażonych kościołów, ale i organizowanie systemu edukacyjnego na wszystkich poziomach - od szkół elementarnych po szkolnictwo wyższe (pierwszy uniwersytet królewski na prawach papieskich i królewskich w Meksyku powstał w 1551; Deslandres 626-627; Morales Valerio 1992c, 118-119; Saranyana i Antonaya 336-338; Gutiérrez Casillas 67-69) oraz dzieł charytatywnych (szpitali, przytułków). Zaangażowanie Korony Hiszpańskiej na tak wielu płaszczyznach wynikało $\mathrm{z}$ wypracowanej i przyjętej strategii, która bazowała na zasadzie cywilizowania (niecywilizowanych) oraz chrystianizowania (pogańskich) ludów autochtonicznych, czyli wprowadzania nowego ładu społecznego i nowej hierarchii wartości, natomiast wykonawcami tego projektu byli przeważnie zakonnicy i duchowni. Pod koniec XVI w. największym skupiskiem klasztorów stała się dolina Meksyku (24 konwenty), Puebla (25 konwentów) i Tlaxcala (12 konwentów) oraz Jukatan (16 konwentów) i Michoacán/Jalisco (ponad 30 konwentów; Milhou 830-835; Morales Valerio 1992d, 103-105; Gómez Canedo 636-640).

Pierwsze próby wprowadzenia chrześcijaństwa na obszarze Meksyku podejmowali zazwyczaj sami konkwistadorzy, na czele z Hernánem Cortésem. 
Jak wynika z zapisków ówczesnych kronikarzy, ich działalność w tym zakresie przejawiała się głównie $\mathrm{w}$ bezwzględnym niszczeniu autochtonicznych miejsc kultu religijnego. W tym celu wdrapywano się na piramidy, aby spektakularnie zniszczyć idole i zmusić ludność do zaprzestania dotychczasowych praktyk religijnych pod groźbą surowych kar, ze śmiercią włącznie (Cortés 46-48). Wydaje się zatem, że zupełnie chybiona jest próba określenia H. Cortésa jako „misjonarza Meksyku”. Był on bowiem jedynie hiszpańskim konkwistadorem, dla którego wiara chrześcijańska nie stanowiła czegoś obcego.

Jest niezaprzeczalnym faktem, że w grupie pierwszych konkwistadorów Meksyku znajdował się duchowny (ks. Juan Díaz Nuñez); nieco później dołączyli mercedariusze (o. Bartolomé de Olmedo i o. Juan de las Varillas) oraz franciszkanie (o. Pedro Melgarejo i o. Diego Altamirano). Mieli oni przede wszystkim zapewnić opiekę duchową Hiszpanom. Nie podejmowali żadnych poważnych wysiłków nawracania Indian, poza próbami nauczenia napotkanych autochtonów podstawowych modlitw chrześcijańskich. Na rozpoczęcie systematycznej i metodycznej ewangelizacji Meksyku nie trzeba było jednak długo czekać. Przybycie pierwszych misjonarzy franciszkańskich i dominikańskich do Nowej Hiszpanii zapoczątkowało zaskakująco dynamicznie rozwijające się dzieło chrystianizacji tego obszaru.

\section{Zasady zaangażowania ewangelizacyjnego według norm zakonnych i synodalnych}

Pierwszą grupę misjonarzy stanowili trzej flamandzcy franciszkanie, którzy przybyli do Meksyku w sierpniu 1523 r. i osiedli się w Texcoco, podejmując trud nauki języka nahuatl (Val 239-240). Jednym z nich był o. Pedro de Gante (1478-1572), inicjator i współtwórca pierwszego katechizmu obrazkowego (catecismos pictográficos; Duran 113-144), nawiązującego do kodeksów azteckich.

Po upływie roku przybyła kolejna grupa franciszkanów, tzw. 12 apostołów Meksyku (Gómez Canedo 147-150). Był to franciszkański projekt ewangelizacyjny, odwołujący się do żywych wówczas na Półwyspie Iberyjskim tendencji mesjanistycznych, a tym samym dążenie do wypracowania zupełnie nowych kryteriów i zasad pracy ewangelizacyjnej, mających na celu stworzenie prekursorskich form „nowego chrześcijaństwa”. W praktyce dla samych franciszkanów oznaczało to: rygorystyczne praktykowanie ubóstwa, postępowanie według ewangelicznego radykalizmu (jeden z franciszkanów stwierdził, że świętość każdego misjonarza jest jak żywe kazanie zastępujące cuda, które odegrały ważną rolę w Kościele pierwotnym; Mendieta 250-251), praktykowanie wędrownego przepowiadania oraz nawracanie Indian bez wsparcia 
konkwistadorów (bez stosowania przemocy oraz siłowej perswazji), rozwijanie działalności ewangelizacyjnej bez wikłania się w zależności finansowe od aparatu kolonialnego, uwzględnienie lokalnych języków (nahuatl) oraz lokalnych elementów kulturowych niebędących w sprzeczności z wartościami chrześcijańskimi (konsekwentne krzewienie kultury chrześcijańskiej). Idealistycznie zakładano, że realizacja powyższych norm przyczyni się do wypracowania i utrwalenia całkowicie nowej jakości praktykowania wiary chrześcijańskiej w ramach wspomnianego już „,nowego chrześcijaństwa”, zupełnie odmiennego od tradycyjnych form europejskich (Bey 22-27). Na uwagę zasługuje fakt, że misjonarze franciszkańscy podejmowali próby stworzenia czegoś zupełnie nowatorskiego, aczkolwiek realia społeczno-polityczne Nowego Świata zweryfikowały pierwotne oczekiwania (Val 269-275). Pomimo niemal całkowitego fiaska owego projektu, pewne jego aspekty znalazły jednak odbicie w praktyce misyjnej franciszkanów. Postawa pierwszych misjonarzy jest przez niektórych współczesnych autorów określana jako na wskroś „,indygenistyczna”, zaangażowana w dzieło ewangelizacji Indian, z uwzględnieniem konieczności posługiwania się miejscowymi językami, studiowania ich kultur, życia pośród ludności pochodzenia autochtonicznego (Gómez Canedo 295-304, 345-352; Chávez 2009, 183-184, 188-189, 201-203; Sahagún 9-13, 20-26).

Przybycie „12 apostołów Meksyku” oznaczało nie tylko wzmocnienie dotychczasowych skromnych sił ewangelizacyjnych, ale zarazem wskazywało na gotowość Korony Hiszpańskiej do konsekwentnego wypełnienia przyjętych obowiązków wynikających z patronatu królewskiego. Natomiast franciszkanie ze swojej strony aktywnie włączyli się nie tylko w ewangelizację Indian, ale również $\mathrm{w}$ budowanie infrastruktury misyjnej oraz zakładanie struktur kościelnych. W 1559 r., a więc niecałe cztery dekady od przybycia pierwszych franciszkanów, w Meksyku funkcjonowało 80 klasztorów i pracowało około 380 ojców oraz braci zakonnych (Alvear Acevedo 63), a pod koniec XVI w. istniało prawie 150 konwentów franciszkańskich.

W 1526 r. w Meksyku miała znaleźć się grupa 12 dominikanów, chociaż nie wszyscy, którzy wyruszyli z Europy, dotarli na miejsce (Medina 1992, 63-64). W roku 1559 pracowało w Meksyku już 210 ojców i braci, żyjących w 40 klasztorach. Świadectwem zaangażowania ewangelizacyjnego dominikanów w Nowej Hiszpanii są liczne monumentalne klasztory, które pełniły podobne funkcje, jak klasztory franciszkanów. Do franciszkanów i dominikanów dołączyło, w 1530 r., 12 mercedariuszy, natomiast w roku 1533 - siedmiu augustianów. Po 29 latach pracowało w Meksyku już 212 augustianów, którzy zajmowali się dziełem ewangelizacji, opierając się na 40 klasztorach. Misjonarze Towarzystwa Jezusowego przybyli na te tereny najpóźniej, bo dopiero w roku 1572. 
Pomiędzy poszczególnymi zakonami zaczęły się dość szybko ujawniać znaczne różnice $\mathrm{w}$ podejściu do pracy misyjnej z ludnością autochtoniczną Meksyku. Franciszkanie żywili silne przeświadczenie, że Indianie mają mocno rozwinięty zmysł religijny i są na ogół otwarci na przyjęcie głoszonej im wiary chrześcijańskiej, o czym świadczyłyby tzw. masowe nawrócenia (Bey 46-50). W Meksyku bowiem po raz pierwszy misjonarze spotkali się ze zjawiskiem masowego zainteresowania chrześcijaństwem ze strony Indian. Tysiące Indian prosiło o chrzest i dopuszczenie do innych sakramentów, w tym sakramentu pokuty (Chávez 2010, 194-198). Z połowy XVI w. pochodzą zapiski kronikarskie, opisujące ogrom pracy ewangelizacyjnej. Franciszkanin znany jako Motolinia pisał, że według jego kalkulacji w latach 1521-1537 chrzest przyjęły co najmniej cztery miliony meksykańskich Indian. Inni zaś donosili w listach, że dziennie udzielali chrztu niemal 14 tysiącom Indian (Bey 326-327, 329-351). Dlatego franciszkanie rozważali już w pierwszych dekadach swojej obecności w Meksyku otwarcie seminarium duchownego na potrzeby przygotowania Indian do przyjęcia święceń, co jednak nie spotkało się z aprobatą władz kościelnych.

Dominikanie natomiast na bazie swoich doświadczeń i oczekiwań byli bardziej powściągliwi w pozytywnej ocenie gotowości Indian do przyjęcia i świadomego praktykowania wiary chrześcijańskiej. Powoływali się na liczne i trudne do wykorzenienia zwyczaje o charakterze idolatrycznym i synkretycznym, praktykowane przez nowo ochrzczonych Indian (Gómez Canedo 81-87). Interesujący opis sporu pomiędzy franciszkanami a dominikanami oraz augustianami, dotyczącego dopuszczenia Indian do sakramentu chrztu świętego, pochodzi z roku 1535 (Bey 323-326).

Z biegiem czasu grupa misjonarzy w Meksyku była już na tyle liczna, że podejmowane różnorakie działania ewangelizacyjne wymagały usystematyzowania (Gutiérrez Casillas 61-64; Alvear Acevedo 87-91). Aby nadać większe znaczenie wysiłkom związanym z planowaniem i koordynacją działań misyjnych, od 1524 r. zaczęto organizować cyklicznie spotkania, tzw. juntas mexicanas (spotkania osób zaangażowanych w dzieło krzewienia wiary chrześcijańskiej; García y García 174-180; Martínez Ferrer i Alejos-Grau 93-101). Pierwsze tego typu spotkanie, znane jako junta apostólica de México, zgromadziło 14 franciszkanów, pięciu księży diecezjalnych oraz cztery osoby świeckie (w tym konkwistadora Hernána Cortésa). Na tych spotkaniach poszukiwano adekwatnych rozwiązań oraz omawiano liczne kwestie sporne, takie jak np. sposoby nauczania i ewangelizowania Indian (jak katechizować; jakie kryteria stosować przy dopuszczaniu Indian do sakramentów; jakim językiem się posługiwać; sensowność zakładania wiosek misyjnych), a także zagadnienia dotyczące wolności Indian (prawo do własności; wprowadzenie w życie tzw. Nowych Praw z 1542) oraz ich predyspozycji do pełnego przyjęcia wiary i ży- 
cia według norm chrześcijańskich. W spotkaniach tych uczestniczyli nie tylko biskupi, przełożeni zakonni i misjonarze, ale też przedstawiciele administracji kolonialnej. Pozwalało to zapoznać się z realnymi problemami i wyzwaniami ewangelizacyjnymi, a zarazem wspólnie poszukiwać optymalnych rozwiązań, co przekładało się jednocześnie na konsolidację lokalnego Kościoła.

Ostatnia junta mexicana miała miejsce w 1546 r., jako że rok później powstała pierwsza archidiecezja na obszarze Meksyku, co umożliwiło zwoływanie synodów prowincjalnych. Na szczególną uwagę zasługują trzy następujące synody z XVI w. (García y García 188-189).

Pierwszy meksykański synod prowincjalny został zwołany w roku 1555, a uczestniczyło w nim pięciu biskupów i wielu delegatów poszczególnych zakonów (Martínez Ferrer i Alejos-Grau 113-118). Dokument końcowy zawiera 93 paragrafy odnoszące się do kwestii dyscypliny kościelnej (praw i obowiązków duchownych) oraz zagadnień dotyczących ewangelizowania i ochrony Indian. Zwrócono też uwagę, że warunkiem udzielania Indianom sakramentów musi być ich wolna wola oraz znajomość przykazań Bożych i podstawowych prawd wiary. Ustalono, że Indianie powinni zostać zgrupowani w wioskach, gdzie będą obowiązywały chrześcijańskie normy i prawa. Zobowiązano się także do podejmowania wysiłków skutkujących sporządzeniem pomocy katechetycznych w językach indiańskich. W latach 1524-1572 ukazało się w Meksyku wiele opracowań dotyczących języków autochtonicznych (słowników i gramatyk oraz pomocy katechetycznych i liturgicznych). Ojciec Alonso Molina, znawca języka nahuatl, opublikował w tym języku Doctrina cristiana (1548), natomiast o. Pedro de Gante nieco wcześniej, bo w 1539 r., swoje opracowanie Doctrina cristiana. W ciągu pierwszych pięciu dekad ewangelizacji Meksyku powstało około 80 pozycji z zakresu lingwistyki, opracowanych przez franciszkanów, 17 tytułów autorstwa dominikanów i osiem pozycji misjonarzy augustianów (Sanchez Herrero 383-389). Pierwszą książką wydrukowaną w Meksyku w drukarni sprowadzonej w roku 1539 była pozycja Breve doctrina Christiana en lengua mexicana y castillana.

Drugi meksykański synod prowincjalny odbył się w 1565 r. i był kontynuacją poprzedniego sprzed 10 lat (Saranyana i Alejos-Grau 137-140). Poświęcono na nim sporo czasu na omówienie dokumentów niedawno zakończonego Soboru Trydenckiego. Na tym synodzie zaakcentowano też m.in. znaczenie znajomości lokalnych języków i posługiwania się nimi przez misjonarzy.

Największe znaczenie miał niewątpliwie trzeci meksykański synod prowincjalny, z 1585 r., nazywany też ,meksykańskim Trydentem”. Wzięli w nim udział biskupi, teologowie, prawnicy i akademicy, przedstawiciele zakonów oraz władzy świeckiej (Martínez Ferrer 181-203; Pérez Puente 126-135). Celem tego synodu było wdrożenie w życie Kościoła w Ameryce Środkowej postanowień Soboru Trydenckiego (konieczność odbywania wizytacji dusz- 
pasterskich przez biskupów; zakres obowiązków duchownych, w tym obowiązek wyjaśniania wiernym Pisma Świętego; zakładanie seminariów duchownych) oraz dookreślenie norm dla bardziej efektywnej pracy ewangelizacyjnej i stanowczej ochrony ludności autochtonicznej. Stąd też wiele czasu poświęcono przedyskutowaniu kwestii wolności Indian, gwarantowanej przez prawo królewskie, w tym skutecznej ich ochrony przed wyzyskiem i niesprawiedliwym traktowaniem. W kwestii obowiązków misjonarzy zwrócono uwagę na konieczność znajomości przez nich języków lokalnych, regularnego odwiedzania powierzonych im wspólnot i prowadzenia systematycznej katechizacji, jak również rozsądnego rugowania wierzeń i praktyk autochtonicznych, sprzecznych z wiarą chrześcijańską (np. kupowania kobiety od jej rodziców albo przymuszania kogoś do zawarcia małżeństwa). Poruszono także kwestię zakładania wiosek misyjnych w celu szybszej chrystianizacji Indian.

W roku 1571, a więc pół wieku po zdobyciu stolicy Tenochtitlán, ustanowiono trybunał inkwizycyjny w celu kontrolowania ortodoksyjności wiary katolickiej w Nowym Świecie, aczkolwiek jurysdykcja tego urzędu nie obejmowała „nowych chrześcijan”, czyli nowo nawróconych Indian (Velásquez García 252; Churruca Paláez 35-39). Wychodzono bowiem z założenia, że Indianie, jako początkujący chrześcijanie, mają prawo przez określony czas nie wykazywać się jeszcze pełną ortodoksyjnością.

\section{Zakonnicy jako protagoniści działalności misyjnej w Meksyku}

Przez długi czas zakonnicy stanowili największą siłę misyjną. Zajmowali się pracą misyjną pośród społeczności indiańskich, obejmując swoją posługą olbrzymie obszary Nowej Hiszpanii.

\section{a. Franciszkanie}

W 1524 r. przybyła grupa franciszkańskich misjonarzy, znana jako „12 apostołów Meksyku”. Zgodnie z przyjętymi normami franciszkańskiego stylu życia udali się z Veracruz do Tlaxcala i dalej do Meksyku na piechotę, zatrzymując się w wioskach indiańskich. Odmawiając podróżowania w asyście uzbrojonych Hiszpanów, dali do zrozumienia, że reprezentują zupełnie odmienny styl zachowania względem ludności tubylczej.

Pięć lat później (1529) dotarła do Nowej Hiszpanii kolejna grupa franciszkanów, w większości akademików, tj. absolwentów uniwersytetu w Salamance i doktorów prawa (Alonso de Herrera i Antonio de Huete oraz Andrés de Olmos i Bernardino de Sahagún). Inni to: Arnaldo de Basacio (muzykolog) 
oraz Juan Focher (doktor prawa z uniwersytetu paryskiego i autor podręcznika omawiającego metody misyjne). Dołączyli do tej grupy jeszcze: Alonso de Molina (wybitny znawca języka nahuatl) i Juan de Torquemada (zasłużony kronikarz).

Najważniejsze konwenty franciszkańskie z okresu pierwszej dekady ewangelizacji powstały w mieście Meksyk, Texcoco, Tlaxcala oraz Huejotzingo. Stały się one centrami misyjnymi i opierając się na nich, prowadzono intensywną działalność misyjną (Chauvet 30-35). Odpowiednio liczna wspólnota franciszkanów pozwoliła na utworzenie już w roku 1535 franciszkańskiej prowincji Santo Evangelio, która pod koniec XVI w. obejmowała 64 konwenty. W kolejnych dekadach powstały nowe prowincje franciszkańskie (Michoacán w 1565 r., Zacatecas w 1603 r.). Na początku XVII w. 50 franciszkanów pracowało wśród 60 tysięcy Indian, zajmując się administracją 25 wiosek misyjnych. W połowie XVIII w. prowincja Santo Evangelio liczyła prawie 750 braci w 71 klasztorach. W drugiej połowie XVIII w. miał miejsce drastyczny spadek liczby franciszkanów oraz klasztorów (sekularyzacja doctrinas).

Poniekąd odrębną kartą historii ewangelizacji Meksyku jest dzieło misyjne na Jukatanie (Morales Valerio 1992e, 205-208). Pierwsza ewangelizacja tego obszaru trwała, w porównaniu z centralnym Meksykiem, dosyć długo. Początki datowane są na rok 1527, ale brak misjonarzy i znaczne oddalenie od ośrodków urbanistycznych, brutalna konkwista i złe traktowanie Indian przez Hiszpanów, brak skutecznej administracji oraz permanentne rebelie indiańskie znacznie utrudniały systematyczną i metodyczną ewangelizację. Sytuacja uległa zmianie, kiedy w 1537 r. na ziemie Majów przybyło pięciu franciszkańskich misjonarzy, pod przewodnictwem doświadczonego misjonarza Jacoba de Testera, wspieranych przez grupę indiańskich współpracowników, gdzie przebywali tylko przez rok. W latach 1544-1545 pracowała tam kolejna grupa franciszkanów, którą uważa się za faktycznych założycieli misji na Jukatanie. Wydaje się, że siły ewangelizatorów były skoncentrowane nie tyle na pracy misyjnej, ile na przezwyciężaniu nadużyć i brutalności konkwistadorów. Przez całe XVI stulecie franciszkanie byli jedynymi misjonarzami na tym olbrzymim obszarze.

\section{b. Dominikanie}

W roku 1526 pracę misyjną rozpoczęli dominikanie. Pomimo personalnych ograniczeń przystąpili do tego zadania z wielkim zaangażowaniem. Dla dominikanów najważniejszym ośrodkiem operacyjnym stało się w 1529 r. miasto Oaxaca, obszar zasiedlany głównie przez Misteków i Zapoteków. Decyzja udania się na południe podyktowana była względami praktycznymi. Chodziło 
bowiem o to, aby niepotrzebnie nie konkurować z franciszkanami. Pod koniec XVI w. w Oaxaca i okolicach dominikanie posiadali 31 konwentów.

Po upływie kilku lat od pojawienia się dominikanów w Nowej Hiszpanii zaczęły funkcjonować ich klasztory również w mieście Meksyk oraz w Gwatemali (Santiago de los Caballeros; Medina 1988, 164-166). W roku 1539 powołana została do życia prowincja Santiago de Mexico i wzniesiono kolejne klasztory (Puebla, Topetloaxto, Oaxtepec, Coyocán itd.). W 1592 r. powstała następna prowincja: w regionie Oaxaca, natomiast w 1656 r. - prowincja San Miguel y Santos Angeles na obszarze Puebla (Medina 1992, 70-79).

W wieku XVII dominikanie skierowali swoją uwagę na północne obszary Meksyku i rozpoczęli pracę ewangelizacyjną w Guadalajara, Zapotecas, Sierra Gorda oraz Dolnej Kalifornii (od 1770, gdy przejęli tamtejsze redukcje jezuickie i założyli nowe wioski misyjne: Nuestra Señora del Rosario - 1774, Santo Domingo - 1775, San Vicente Ferrer - 1780, San Miguel Arcángel - 1787, Santo Tomás de Aquino - 1791, San Pedro Mártir - 1794 i Santa Catalina 1797). Natomiast w 1808 r. powstała nowa prowincja: San José de Chiapas.

Na potrzeby pracy ewangelizacyjnej dominikanie wypracowali charakterystyczną strategię. W dużych centrach urbanizacyjnych zakładali konwenty miejskie, które były oparciem dla pracy z Indianami żyjącymi w miastach oraz dla pracy duszpasterskiej z Hiszpanami, natomiast $\mathrm{w}$ interiorze funkcjonowały wikariaty (vicarías de indios) na potrzeby pracy misyjnej pośród ludności autochtonicznej (Medina 1992, 96-101). Taka strategia była owocem długich dysput dotyczących tego, czy pracować, opierając się wyłącznie na konwentach miejskich, czy też rozbudować sieć mniejszych, ale liczniejszych placówek misyjnych w pobliżu skupisk indiańskich. Zatriumfowała druga opcja, w wyniku której dominikańscy misjonarze osiedlili się głównie w regionie Oaxaca, na obszarze zasiedlanym przez Misteków, Zapoteków i Chichimeków. Zwyciężył bowiem pogląd, że stała obecność zakonników w interiorze pośród ludności autochtonicznej będzie sprzyjającym aspektem w pracy misyjnej. O ile było to możliwe, starano się zakładać centra misyjne w miejscach strategicznych i ważnych dla społeczności indiańskich (pod względem administracyjnym albo religijnym). Nieliczna grupa misjonarzy, mieszkająca $\mathrm{w}$ poszczególnych centrach misyjnych, obsługiwała nawet do kilkunastu wiosek indiańskich. W roku 1559 pracowało w Meksyku 210 dominikanów, tworząc 40 wspólnot zakonnych. Ten zapał misyjny wygasł pod koniec okresu kolonialnego. Dominikanie wycofali się wówczas z wielu prowadzonych misji i skoncentrowali się na pracy w większych centrach urbanizacyjnych.

Dominikanie przywiązywali wielką wagę nie tylko do szerzenia wiary i kultury chrześcijańskiej, ale byli też bardzo aktywni w zakresie edukacji (Medina [1988] 166-168), jak również agrokultury (rolnictwa i hodowli), 
wprowadzając nowe metody pracy i nowe typy upraw (Medina 1992, 104-106). Zajmowali się także tworzeniem wielkich dzieł architektonicznych: kościołów (Oaxaca) i konwentów (klasztory wokół miasta Meksyk, stacje misyjne w Dolnej Kalifornii).

\section{c. Augustianie}

Pierwsza siedmioosobowa grupa augustianów przybyła do Meksyku w roku 1533. Powstały wówczas ich klasztory w okolicach miasta Meksyk (jednym z bardziej znanych konwentów jest Acolmán) i Puebla oraz na obszarze Sierra Gorda (w Xilitla - 1553) czy też na terenach dzisiejszego stanu Guerrero. Zostali jednak zachęceni, aby udać się na miejsca, które nie były jeszcze objęte pracą misyjną przez inne zakony. Dlatego założyli swoje klasztory w Hidalgo (20 konwentów), natomiast w Michoacán powstały nie tylko liczne konwenty, ale również pierwsze centrum studiów teologicznych. Pod koniec XVI w. rozwijali swoją działalność misyjną i ewangelizacyjną, opierając się na 80 klasztorach.

Praca augustianów została wydatnie osłabiona w roku 1754, kiedy to ukazał się dekret dotyczący przekazania doktryn prowadzonych przez zakonników w ręce kleru diecezjalnego (tzw. secularización de las doctrinas). O zaangażowaniu augustianów w dzieło misyjne Meksyku świadczą chociażby opracowania lingwistyczne. Diego Basalenque jest autorem Arte de la lengua matlatzinca, natomiast Miguel de Guevara - Arte doctrinal y modo de aprender la lengua matlatzinca.

\section{d. Jezuici}

Misjonarze Towarzystwa Jezusowego przybyli do Nowej Hiszpanii w 1572 r. (Santos Hernández 20-32; Szyszka 75-79, 157-193). Po upływie roku założyli kolegium San Pedro y San Pablo w mieście Meksyk oraz zaangażowali się w dzieło edukacji i formacji. W 1577 r. powołano do życia prowincję, która liczyła 78 członków pracujących w kilkunastu jezuickich kolegiach w ważniejszych miastach (Meksyk, Pátzcuaro, Oaxaca, Puebla, Guadalajara, Zacatecas i Durango na północy; Fernández Galiano 185-187). W połowie XVII w. prowincja liczyła już ponad 400 członków. W ośrodkach miejskich jezuici prowadzili kolegia, seminaria i uniwersytety, a także działalność o charakterze naukowym oraz zajmowali się duszpasterstwem. Pod koniec XVI w. podjęli pracę misyjną wśród ludności autochtonicznej na północy ówczesnego Meksyku (w Zacatecas, Sinaloa, Durango, Chihuahua, Tarahumara; Morales 
Valerio 1992b, 166-168; Gutiérrez Casillas 76-81; Velásquez García 285-289). Zaangażowanie misyjne jezuitów w założenie 17 wiosek misyjnych na półwyspie Dolnej Kalifornii miało miejsce od roku 1697 do 1767 (Morales Valerio 1992a, 125-144).

\section{Metodologia misyjna w Meksyku}

Specyficzny kontekst społeczno-kulturowy Nowej Hiszpanii stał się bodźcem do wypracowania nowych, odpowiednich strategii misyjno-ewangelizacyjnych. Misjonarze zdawali sobie sprawę z konieczności kreatywnego i zaangażowanego oddania się pracy misyjnej (Gómez Canedo 184-295). Zdołano wypracować jej metodologię, która przyczyniła się do efektywnej realizacji spoczywających na nich obowiązków.

\section{a. Edukacja}

Protagonistami edukacji w Meksyku byli franciszkanie. Jako pierwsi zainicjowali edukację Indian, tworząc system szkół elementarnych i zawodowych (centros artes y oficios albo artes mecánicas) oraz kolegiów dla synów z rodzin lokalnej arystokracji (Morales Valerio 1992c, 117-118; Val 242-249; Alvear Acevedo 127-130). Pierwsze centrum edukacyjne powstało w $1523 \mathrm{r}$. w Texcoco, rok później w mieście Meksyk (San José de Belén de los Naturales), a kolejne $\mathrm{w}$ Tlaxcala $\mathrm{w}$ roku 1527. Zajmowano się również edukacją dziewcząt, której pionierami także byli franciszkanie. Założyli oni w $1529 \mathrm{r}$. w Texcoco szkołę dla dorosłych dziewcząt, a po pięciu latach przyjęte zostały również młodsze dziewczęta.

Tym samym już w latach dwudziestych XVI w. franciszkanie stworzyli sobie przestrzeń dla systematycznej formacji kilkuset osób pochodzenia autochtonicznego. Zakładane szkoły pozwalały nie tylko na prowadzenie regularnej edukacji oraz formacji religijnej młodych Meksykanów, ale także na wykształcenie grupy odpowiedzialnych współpracowników pochodzenia autochtonicznego (nauczycieli i formatorów w szkołach oraz na potrzeby ewangelizacji świeckich pomocników misjonarzy). W szkołach uczono nie tylko posługiwania się alfabetem łacińskim (czytania i pisania), ale też gry na instrumentach (organach), a w niektórych kolegiach nawet łaciny. Muzyka i śpiew były wykorzystywane głównie do celów liturgicznych. Przyjmuje się, że w roku 1531 (dziesięć lat po pokonaniu Montezumy II) w szkołach zakonnych naukę pobierało około 5 tysięcy uczniów. Dzięki temu wielu Indian miało wykształcenie co najmniej podstawowe oraz zawodowe. 
Dobrym przykładem osiągnięć edukacyjnych franciszkanów było kolegium Santa Cruz de Tlatelolco, założone w 1536 r. Program edukacji obejmował tam m.in. nauczanie gramatyki (języka hiszpańskiego i łaciny), filozofii, retoryki, teologii, medycyny, astronomii itd. Wysoki poziom tej szkoły skłonił franciszkanów do rozważenia możliwości przygotowania najbardziej uzdolnionych Meksykanów do przyjęcia święceń (Chávez 2009, 207-208). Osoby związane właśnie z tym ośrodkiem opracowały znany tekst „Nican mopohua" w języku nahuatl, opisujący objawienia Maryi z roku 1531 w Guadalupe (Chávez 2010, 77-81).

Szkoły i kolegia służyły nie tylko edukacji Indian, ale też samych misjonarzy, którzy uczyli się miejscowych języków, zgłębiali lokalne kultury, pracowali nad thumaczeniami katechizmów, opracowywali pomoce liturgiczne oraz dzieła z zakresu etnologii. W niektórych szkołach uczniowie byli zarazem nauczycielami języka nahuatl dla nowo przybyłych misjonarzy oraz ich przewodnikami po miejscowych kulturach. W ten sposób wiedzę o Meksyku zdobywał m.in. franciszkanin Bernardino de Sahagún, autor trójjęzycznego Kodeksu florenckiego (Códice Florentino) oraz rewelacyjnego dwunastotomowego dzieła Historia general de las cosas de Nueva España. Uważany jest on za ojca antropologii meksykańskiej. Zasłużył na to określenie dzięki wieloletnim badaniom historii i kultury azteckiej.

Na uwagę zasługuje śmiałe zastosowanie przez franciszkanów miejscowego systemu calmecatl, czyli odwołanie się do autochtonicznych tradycji (wiedzy z zakresu nauk przyrodniczych i historii, tradycyjnych form przekazywania wiedzy, pielęgnowania tradycji muzycznych itd.). Natomiast rozwinięcie metody „kwiat i śpiew” (la flor y el canto) przyczyniło się do wykorzystania naturalnych predyspozycji tamtejszych Indian do wypracowania nowych tradycji, takich jak np. uroczyste celebracje religijne (Ricard 282-303).

W 1683 r. powołano do życia w miejscowości Querétaro pierwsze w Nowym Świecie Colegio de Propaganda Fide de la Santa Cruz (Misyjne Kolegium Apostolskie Rozkrzewiania Wiary Świętego Krzyża) na potrzeby pracy misyjnej na obszarze Zacatecas, Nayarit oraz Teksasu (Deslandres 641).

\section{b. Teatr ewangelizacyjny}

Kolejnym bardzo istotnym elementem metody misyjnej w Meksyku były przedstawienia religijne (Baraniecka 15-19; Ricard 304-319; Val 250-251; Gómez Canedo 295, 374). Tę formę ewangelizacji Indian meksykańskich zainicjowali franciszkanie i dominikanie, nawiązując do swoich wcześniejszych, europejskich doświadczeń w tym zakresie, jak również do bogatej, lokalnej tradycji meksykańskiej. Bazowano głównie na staro- i nowotestamentowych 
tematach biblijnych oraz na wątkach hagiograficznych, wykorzystywano też lokalne przekazy i legendy, a także odwoływano się do autochtonicznych obrzędów. Aktorami byli sami Indianie, natomiast językiem narracji nahuatl albo inne języki lokalne. Bardzo ważny aspekt tych inscenizacji stanowiło wykorzystanie autochtonicznych wyrazów ekspresji, takich jak: śpiew, taniec, muzyka, formy kreacji itd.

Najwięcej udokumentowanych tekstów przedstawień pochodzi z Tlaxcala z drugiej połowy czwartej dekady XVI w., aczkolwiek podobne wydarzenia artystyczne organizowano w rozmaitych zakątkach Meksyku. Miały one wielkie znaczenie katechetyczne, ponieważ wizualizowały główne prawdy wiary chrześcijańskiej, co ułatwiało ich zrozumienie i przyjęcie oraz motywowało Indian do aktywnego uczestniczenia w życiu religijnym i pobudzało ich zmysł religijny (Baraniecka 37-69). Były one ważnym elementem świąt i uroczystości kościelnych, dodając nie tylko splendoru, ale i przekazując w przystępny sposób tematykę poszczególnych uroczystości (np. narodzin Jezusa, Jego zmartwychwstania, Bożego Ciała itd.).

\section{c. Sztuka sakralna i architektura, muzyka i śpiew}

W imperium azteckim sztuka (malarstwo, rzeźba) i muzyka, w tym śpiew, odgrywały niebagatelną rolę (Ricard 264-281; Morales Valerio 1992c, 120-121; Martín Rivera 152-156). Nie dziwi zatem fakt, że misjonarze wykorzystywali hiszpańskich artystów (np. Rodrigo de Cifuentes zajmował się wystrojem konwentów w Tlaxcala, tworząc dzieła przedstawiające arystokrację indiańską, nawróconą na chrześcijaństwo, np. El bautizo de los caciques de Tlaxcala), aczkolwiek świadomie nawiązywano do autochtonicznych tradycji, uwzględniając uzdolnienia i predyspozycje Indian. Należy bowiem zauważyć, że przed przybyciem Hiszpanów do Meksyku już istniały tam dzieła architektury i sztuki na bardzo wysokim poziomie. Stąd też przy powstawaniu konwentów dużą wagę przywiązywano do architektury i sztuki sakralnej, którym przypisywano charakter katechetyczno-ewangelizacyjny. Na podwórzach klasztorów stawiano kaplice, które służyły do modlitwy albo jako ołtarze podczas procesji, natomiast na środku placów umieszczano krzyże na podwyższeniu ze stopniami. Klasztory były wielkie, aby mogły sprostać licznym zadaniom ewangelizacyjnym, jakie wzięli na siebie zakonnicy. Kościoły były przestrzenne i bogate, zazwyczaj w stylu barokowym. Bogactwo elementów architektonicznych, malowidła, freski, rzeźby, kamienne krzyże, nastawy ołtarzowe, metaloplastyka oraz sztukateria i wyroby jubilerskie miały podkreślać szczególny sakralny charakter świątyń. Na uwagę zasługują przepiękne kościoły w Acolmán, Cholula, Cuernavaca, mieście Meksyk, Puebla, na Jukatanie itd. 
Na potrzeby pracy z Indianami funkcjonowały specjalne „kaplice Indian”, wkomponowane $\mathrm{w}$ zabudowę klasztorną. Stanowiły one specyficzną przestrzeń ewangelizacyjno-liturgiczną. Były to otwarte na dziedziniec prezbiteria, w których znajdował się jedynie ołtarz, obraz albo freski. Kaplice te znajdowały się na poziomie ziemi lub na podwyższeniu, aby zapewnić wszystkim dobrą widoczność. Stanowiły one idealną scenerię, zwykle z dobrą akustyką, dla obrazowego nauczania katechizmu oraz sprawowania liturgii. Przestrzeń ta była wykorzystywana również do przedstawień teatralnych.

$\mathrm{Na}$ olbrzymich klasztornych podwórzach gromadzono liczne grupy Indian na naukę, utrwalanie katechizmu i liturgię. Dzieci zbierały się tam codziennie lub kilka razy w tygodniu, natomiast dorośli - w niedziele i święta. Katecheza polegała na nauczaniu prawd wiary chrześcijańskiej, a środkami pomocniczymi były: śpiew, malunki, obrazy i przenośne scenerie. Borykając się z kwestią masowych nawróceń, misjonarze wprowadzili katechezę przedchrzcielną i pochrzcielną w celu utrwalenia i pogłębiania znajomości prawd wiary przez neokatechumenów. Jeden z franciszkańskich misjonarzy napisał, że sam tylko w 1529 r. ochrzcił kilkadziesiąt tysięcy Indian. Takie zaangażowanie wymagało adekwatnych przygotowań, ale też infrastruktury. Służyły temu właśnie wielkie konwenty.

Kolejnym zakresem ewangelizacyjnej kreatywności było tworzenie nowych tradycji muzycznych z wykorzystaniem europejskich i autochtonicznych instrumentów oraz form jej wykonywania (rytmu, dynamiki, harmonii). Nauczanie muzyki w ośrodkach edukacyjnych cieszyło się wielkim zainteresowaniem. Stąd też bardzo szybko powstały liczne grupy muzyczne i śpiewacze, które wykonywały nie tylko religijne utwory pochodzenia europejskiego, ale i muzykę zakorzenioną w tradycji lokalnej, odwołując się do języków autochtonicznych (głównie nahuatl). W XVI w. zaczęto produkować organy oraz inne instrumenty na własne potrzeby. Muzyka, podobnie jak sztuka i teatr, była postrzegana jako ważny środek ewangelizacyjny. W $1524 \mathrm{r}$. franciszkanie z Texcoco założyli pierwszą w Meksyku szkołę muzyczną dla indiańskich dzieci. $Z$ biegiem czasu podobnych ośrodków edukacji i propagowania muzyki oraz śpiewu sakralnego powstawało więcej, tym bardziej że zapotrzebowanie było wielkie, gdyż przy każdym niemal kościele istniała grupa śpiewaków i muzyków (Alvear Acevedo 135-136; Gómez Canedo 295, 371-374, 453).

Zachowały się interesujące przekazy przeżywania różnorodnych nabożeństw, podczas których adoracji Najświętszego Sakramentu towarzyszyła odpowiednia oprawa: muzyka, śpiew, kwiaty, świece i kadzidło (Martín Rivera 141-143, 146-152). Jeszcze barwniej wyglądały nabożeństwa związane z procesjami organizowanymi przez bractwa religijne, podczas których tworzono 
dywany kwiatowe, odpowiednio ubrani ludzie dźwigali specjalnie przystrojone feretrony z wizerunkami świętymi, a grupy muzyków i śpiewaków zapewniały całości wyjątkowo uroczysty charakter.

\section{d. Nauczanie katechetyczne i przepowiadanie}

Niezaprzeczalnym faktem jest, że edukacja, teatr, sztuka i muzyka były w XVI w. w Meksyku istotnymi elementami metodologii misyjnej. Misjonarze z poszczególnych zakonów wielkie znaczenie przypisywali słowu głoszonemu w postaci katechezy i kazań (Morales Valerio 1992a, 128-130; Val 256-258). Tym samym musieli stawić czoła problemowi inności kulturowej, w tym odmienności i różnorodności językowej. Dlatego też skoncentrowano się na języku nahuatl, czyli na lingua franca azteckiego imperium. Franciszkanin Pedro Gante opracował wprawdzie pierwszy katechizm obrazkowy i znalazł naśladowców, ale dość szybko zarzucono ten projekt, skupiając się na opracowaniach z zakresu lingwistyki. Przygotowywano słowniki i gramatyki, aby na ich bazie stworzyć pierwsze katechizmy w językach indiańskich, które to opracowania były konsekwentnie poprawiane i ulepszane (Ricard 109-137). Poszukiwano w religijnych tradycjach autochtonicznych nazw, które można byłoby zapożyczyć do wyrażenia prawd chrześcijańskich (np. Ipalnemoani Dawca Życia; Temaquixtiani - Wyzwoliciel ludzi, określenie stosowane do Osoby Jezusa Chrystusa). Rozmach tworzenia materiałów katechetycznych oddają liczby: na przestrzeni pierwszego półwiecza chrystianizacji Meksyku powstało ponad sto pozycji w różnych językach lokalnych (np. nahuatl, język Tarasków, Majów itd.). Do końca XVIII w. wydano w Meksyku kilkanaście tysięcy pozycji (Alvear Acevedo 116-119). Drukarnie klasztorne przygotowywały podręczniki szkolne, katechizmy, gramatyki, słowniki miejscowych języków, śpiewniki itd.

$\mathrm{Na}$ uwagę zasługują wysiłki pierwszych misjonarzy Meksyku, np. o. Jacoba de Testera, który przybył do Meksyku w roku 1529. Wprawdzie poznał język nahuatl, ale był też zainteresowany przygotowaniem bardziej zrozumiałych dla Indian pomocy katechetycznych. W tym celu opracował system znaków graficznych (tzw. escritura testeriana), które miały ułatwić zapamiętywanie prawd wiary. Tak powstał ikonograficzny środek mnemotechniczny na potrzeby ewangelizacji Meksyku (Mendieta 246).

Równie interesująca była metoda opracowana przez o. Toribia de Benavente, znanego bardziej jako Motolinia, a pracującego w Cholula. Należał on do grupy franciszkańskich misjonarzy, którzy podeszli bardzo kreatywnie do wykorzystania pisma obrazkowego (Gómez Canedo 217-222). Otóż w 1537 r. 
w okresie Wielkiego Postu było wielu Indian chętnych do skorzystania z sakramentu pokuty, a dodatkową trudność stanowiła różnorodność językowa. Aby temu zaradzić, polecono penitentom wcześniejsze zapisanie swoich win za pomocą figur, opracowując niejako „osobisty wykaz grzechów”. Ta metoda znacznie ułatwiła spowiedź, aczkolwiek problem stanowił nieskodyfikowany wykaz figur (Duran 103).

Wielkim szacunkiem oraz przywilejami cieszyli się predicadores (kaznodzieje), na co wskazują ówczesne dokumenty kościelne i zakonne. Ich zadaniem było nie tylko głoszenie słowa Bożego, ale i nawoływanie do nawrócenia „starych chrześcijan”, czyli Hiszpanów i ich potomków, oraz „nowych chrześcijan” wywodzących się z ludności autochtonicznej.

\section{e. Rodzime kultury jako wyzwanie}

Początkowo działalność misyjna bazowała wprawdzie na nauczaniu katechizmowym, choć na charakter pierwszych kontaktów pomiędzy misjonarzami a ludnością autochtoniczną zasadniczy wpływ wywierała jednak metoda tabula rasa, nieuwzględniająca bogactwa miejscowych kultur i środków wyrazu religijnego oraz nieszanująca lokalnych tradycji i historii. Misjonarze potrzebowali nieco czasu, aby dostrzec potencjał ewangelizacyjny, drzemiący w społecznościach autochtonicznych (Borges 498-501; Morales Valerio 1992a, 133-136). W tym właśnie kontekście na szczególną uwagę zasługuje chociażby franciszkanin Bernardino de Sahagún (1500-1590), autor dzieła Libro de los coloquios y la doctrina cristiana (1564). Dążył on do dogłębnego poznania lokalnych kultur oraz ich opisania. W latach 1536-1550 pracował w kolegium franciszkańskim Santa Cruz w Tlatelolco, gdzie był zarazem nauczycielem i uczniem, studiując język nahuatl oraz miejscowe zwyczaje i tradycje. Tego typu zaangażowanie w opisywanie pogańskich zwyczajów budziło liczne zastrzeżenia, znajdując swój wyraz w rozporządzeniu króla Filipa II z roku 1577. Nakazano skonfiskowanie i zniszczenie całego opracowanego materiału, co zrealizowano tylko częściowo (Milhou 804-808). Nastawienie samego Bernardina de Sahagún do kultur autochtonicznych może wydawać się ambiwalentne, o czym świadczy następujący tekst:

Lekarz powinien być biegły w znajomości chorób i lekarstw przeciwko każdej dolegliwości. A jako że kaznodzieje i spowiednicy są lekarzami duszy, dla uleczenia przypadłości tejże dobrze jest, by znali choroby duchowe: kaznodzieja, by móc nauczać przeciw nałogom duszy, spowiednik zaś, by wiedzieć, o co i jak pytać, by zrozumieć, o czym mu penitent opowiada (Dembicz 82). 
Z powyższego tekstu wynika, że dążenie ewangelizatorów do dogłębnego poznania lokalnych kultur nie wynikało z czczej ciekawości lub błahych pobudek, ale z potrzeby efektywnej pracy ewangelizacyjnej. Misjonarze zdawali sobie sprawę z konieczności odnalezienia się w tym tak bardzo odmiennym środowisku społeczno-kulturowym, czego przejawem był chociażby obowiązek znajomości i posługiwania się językiem nahuatl. Kierując się gorliwością nawracania oraz chęcią skutecznego zakorzeniania wiary chrześcijańskiej i rugowania idololatrii, poczuwali się do obowiązku unicestwiania miejsc, tradycji i elementów kultów autochtonicznych, np. składania krwawych ofiar z ludzi i ze zwierząt. W tym celu niszczono świątynie i usuwano z nich wszelkiego rodzaju idole. Starano się również ograniczyć do minimum oddziaływanie rodzimych szamanów czy też kapłanów religii niechrześcijańskiej, czego dowodem jest tragiczny los dwóch Zapoteków, którzy zginęli śmiercią męczeńską 16 września 1700 r. w San Francisco Cajonos (beatyfikowani przez Jana Pawła II w roku 2002). Dlatego podejmowane wysiłki w tym zakresie były określane jako „konkwista duchowa” (Alvear Acevedo 106-108; Gómez Canedo 38, 84, 271, 274, 276; Aramoni Calderón 369-380).

Na to, jak ważnym aspektem było właściwie zrozumienie adresata przepowiadania, wskazuje badaczka Meksyku Maria Frankowska:

Misjonarze nie rozumieli właściwie reakcji odbiorców ich nauk, którzy najczęściej interpretowali nadawane im komunikaty z zakresu podstaw nowej religii, jej liturgii czy też symboliki w sposób zgoła odmienny od intencji misjonarzy katolickich, zgodny natomiast z założeniami ich dawnego, rodzimego systemu ideologicznego (Frankowska 86).

Powyższe stwierdzenie można uzupełnić stosunkowo licznymi przykładami. Otóż sukcesy ewangelizacyjne, tj. szybkie i w miarę łatwe nawracanie Indian na chrześcijaństwo, miały także swoje drugie oblicze. Często zdarzało się, że Indianie masowo i dobrowolnie przyjmowali chrześcijaństwo, praktykowali wiarę chrześcijańską, ale nie rezygnowali całkowicie z dotychczasowych praktyk religijnych o charakterze idolatrycznym. Przykładem jest wioska Maní na Jukatanie, gdzie w roku 1562 (po 12 latach pracy ewangelizacyjnej) odkryto grupę Indian, którzy powrócili do składania ludzi w ofierze bóstwom (Morales Valerio 1992e, 204). W takich przypadkach misjonarze musieli wykazać się wielką roztropnością. Nie mogli tolerować takiego zachowania Indian, ale nierozważne decyzje mogły skutkować rebelią. Takie sytuacje zdarzały się jednak bardzo często. Konsekwencją owego wielowiekowego niezrozumienia są rozmaite formy praktyk synkretycznych, które przetrwały do czasów współczesnych. 


\section{f. Opieka medyczna}

Bardzo ważnym elementem w pracy ewangelizacyjnej okresu kolonialnego w Meksyku od XVI w. była fachowa opieka sprawowana nad chorymi, trędowatymi i umierającymi (Alvear Acevedo 70-72; Churruca Paláez 52-54; Martín Rivera 160-163). To zadanie realizowano w lecznicach istniejących we wszystkich większych miastach i niemalże przy każdym konwencie. Były one dostępne również dla ludności autochtonicznej (np. Hospital Real de Naturales), a medycy zobowiązani zostali do znajomości lokalnych języków. Prowadzeniem ośrodków pomocy zdrowotnej zajmowali się kamilianie, betlejemici i kilka innych zakonów, w tym żeńskie. Takie miejsca odgrywały niezmiernie ważną rolę podczas licznych epidemii, które dziesiątkowały społeczeństwo. Na szczególną uwagę zasługuje nowatorski projekt w Michoacán na potrzeby Indian Tarascos. Biskup Vasco de Quiroga, znany jako Tata Vasco, w drugiej połowie XVI w. założył tzw. pueblos-hospitales, które odegrały znaczącą rolę w ochronie i niesieniu konkretnej pomocy tamtejszym Indianom (Martín Rivera 110-111).

\section{g. Ochrona ludności autochtonicznej}

W dobie konkwisty i późniejszej działalności kolonizacyjnej to właśnie zakonnicy zdecydowanie stawali po stronie Indian, będąc ich obrońcami, głosem w ich sprawie na dworze królewskim w Hiszpanii oraz w urzędach kolonialnych. Pomimo wielorakich powiązań, a nawet uzależnienia misjonarzy od urzędników aparatu kolonialnego oraz encomenderos (właścicieli ziemskich), wielu z nich brało stronę Indian, akcentując konieczność poszanowania ich godności osobistej oraz prawa do własności i życia w wolności (Velásquez García 184-185). Uwzględniając takie czy inne ograniczenia wynikające z ducha ówczesnej epoki, to właśnie misjonarze starali się traktować Indian po ludzku, co wyraziło się w dostrzeżeniu i dowartościowaniu ich zdolności do pełnego przyjęcia wiary chrześcijańskiej (kierowania się w życiu nadzieją i nieulegania pesymizmowi czy też myśleniu katastroficznemu; praktykowania chrześcijańskich wartości, takich jak przebaczenie i pojednanie), a tym samym do bycia aktywnym podmiotem $\mathrm{w}$ procesie zachodzących transformacji kulturowych. W różnych regionach Meksyku dynamika tego procesu była rozmaita i przynosiła mniej lub bardziej zaskakujące efekty.

$\mathrm{Na}$ szczególną uwagę zasługuje w tym kontekście misyjny eksperyment bp. Vasca de Quiroga, inicjatora tzw. pueblos-hospitales z roku 1532 i 1533. Założył on dwie „wioski ucieczek” (jedną w Michoacán, drugą w pobliżu miasta Meksyk; Milhou 812-815). Wioski misyjne były też zakładane przez 
franciszkańskich i dominikańskich misjonarzy. Jednym ze zwolenników i propagatorem tej metody był bp Juan Zumárraga z Meksyku (1534-1536). Nieco później (1537) pracujący w Oaxaca dominikanie zgłosili postulat, aby ewangelizowanych Indian nakłonić do zamieszkania w wioskach tworzonych według hiszpańskiego modelu (plac główny i siatka ulic, kościół i urzędy, domostwa). W ciągu kolejnych dwóch dekad powstało kilkadziesiąt takich wiosek. Fenomenem stały się nieco później redukcje jezuickie (przejęte w 1770 r. przez dominikanów) na północnym zachodzie Meksyku (Dolna Kalifornia; Fernández Galiano 193-196).

$*$

Historia ewangelizacji Meksyku w XVI i XVII w. ma tak wiele różnorodnych wymiarów, że z pewnością zasługuje na pełniejsze poznanie. Przedstawiony powyżej zarys zmagań ewangelizacyjnych w Nowej Hiszpanii powinien stać się dla zainteresowanych osób bodźcem do systematycznych studiów, które obejmą sporo rozmaitych aspektów z pogranicza historii Kościoła i historii ewangelizacji Nowego Świata, historii Meksyku i antropologii kulturowej (Synowiec 41-42, 62-64). Jest to tym ważniejsze, że próby dyskursu historycznego, dotyczącego Meksyku, przybierają bardzo często różnorodne odcienie ideologiczne, zazwyczaj niechętne religii chrześcijańskiej.

Historia chrystianizacji Meksyku uczy, że zaangażowanie misjonarzy reprezentujących poszczególne zakony przybierało $\mathrm{w}$ okresie kolonialnym rozmaite formy i było realizowane z większym lub mniejszym nakładem sił i środków, aczkolwiek dzieło to konsekwentnie rozwijano (Gómez Canedo 137-139). Wiele z podejmowanych wówczas dzieł przetrwało do czasów współczesnych, chociażby w postaci architektury (starych kościołów i ośrodków zakonnych), sztuki sakralnej, zachowanych struktur wiosek misyjnych, bractw kościelnych, licznych artefaktów muzealnych (katechizmów obrazkowych), ale nade wszystko rozlicznych tradycji religijnych, w tym żywej religijności ludowej.

Poznanie najważniejszych aspektów ewangelizacji Meksyku jest istotnym przyczynkiem do poznania historii chrystianizacji całej Ameryki Łacińskiej. Wypracowana bowiem w Meksyku metodologia misyjna znalazła zastosowanie w innych regionach tego kontynentu. Misjonarze ze świata andyjskiego i innych części Ameryki Południowej odwoływali się do wzorców wypracowanych właśnie w Meksyku.

Wydaje się zatem, że prawdziwa fascynacja historią Meksyku powinna zawsze uwzględniać wiarygodne źródła historyczne, w tym rzetelne informacje z zakresu chrystianizacji tego kraju, i odwoływać się do nich. Zastosowane 
bowiem przed kilku wiekami metody i środki misyjne, za pomocą których osiągnięto wybitne efekty ewangelizacyjne, mogą być ważkim punktem odniesienia również dla współczesnych wysiłków ewangelizacyjnych, czyli dla realizacji programu ewangelizacji integralnej.

\section{AN OUTLINE OF THE HISTORY OF THE EVANGELIZATION OF MEXICO IN THE $16^{\mathrm{TH}}-17^{\mathrm{TH}}$ CENTURY}

\section{Summary}

The evangelization of Mexico in the $16^{\text {th }}$ and $17^{\text {th }}$ centuries is a fascinating period in the history of Christianization of the New World. The creative confrontation of the then missionaries (Franciscans, Dominicans, Augustinians, and Jesuits) with local cultures and beliefs and the Spanish conquest system resulted in the development of innovative methods of working with indigenous peoples (catechisms, education, art, hospitality, scientific research) and the creation of stable church structures in Mexico.

Keywords: Mexico; evangelization; Indians; catechisms; Franciscans; Dominicans; Jesuits

Słowa kluczowe: Meksyk; ewangelizacja; Indianie; katechizmy; franciszkanie; dominikanie; jezuici

\section{BIBLIOGRAFIA}

Alvear Acevedo, Carlos. La Iglesia en la historia de México. México: Editorial Jus, 1995.

Aramoni Calderón, Dolores. „Iglesia, cultura y represión entre los zoques de Chiapas en el siglo XVII.” Catolicismo y Extirpación de Idolatrías. Siglos XVI-XVIII. Red. Gabriela Ramos, Henrique Urbano. Cusco: Centro de Estudios Regionales andinos „Bartolomé de las Casas”, 1993. 367-387.

Baraniecka, Kamila. Teatr ewangelizacyjny w Nowej Hiszpanii w szesnastym wieku. Dokumenty robocze $\mathrm{nr}$ 48. Warszawa: Cesla, 2007.

Bey, Horst von der. „Auch wir sind Menschen so wie ihr!”. Franziskanische Dokumente des 16. Jahrhunderts zur Eroberung Mexikos. Paderborn: Schöning, 1995.

Borges, Pedro. „La metodología misional americana.” Historia de la Iglesia en Hispanoamérica y Filipinas (siglos $X V$-XIX). Red. Pedro Borges. Vol. 1. Madrid: Biblioteca de Autores Cristianos, 1992. 495-507.

Chauvet, Fidel. „Las misiones franciscanas.” Historia general de la Iglesia en América Latina: México. Red. Enrique Dussel. Vol. 5. Salamanca: Ediciones Sígueme, 1984. 28-48.

Chávez, Eduardo. Drugi całun. Matka Boża z Gwadelupy - wyzwanie dla nauki, historii i wiary. Tłum. Agnieszka Fijałkowska Żydok. Kraków: Wydawnictwo M, 2010.

Chávez, Eduardo. La Verdad de Guadalupe, México: Ediciones Ruz, 2009.

Churruca Paláez, Agustín. Historia de la Iglesia en México. México: Buena Prensa, A.C., 2005. 
Coe, Michael. Ameryka prekolumbijska. Tłum. Hanna Turczyn-Zalewska. Warszawa: Świat Książki, 1997.

Cortés, Hernán. Listy o zdobyciu Meksyku. Tłum. Maria Mróz, Ryszard Tomicki. Gdańsk: Novus Orbis, 1997.

Dembicz, Andrzej. Filozofia poznania Ameryki, Warszawa: Cesla, 2006.

Deslandres, Dominique. „Das Christentum in Süd und Nordamerika.” Die Geschichte des Christentums. Red. Pietri Jean-Marie Mayeur. Band 9. Freiburg im Breisgau: Herder, 1998. 613-661.

Duran, Juan Guillermo. Monumenta Catechetica Hispanoamericana (siglos XVI-XVIII). Vol. 1. Buenos Aires: Facultad de Teología de la PUCA Santa Maria de los Buenos Aires, 1984.

Fernández Galiano, María José. „México: La evangelización de Baja California.” Historia de la Iglesia en Hispanoamérica y Filipinas (siglos XV-XIX). Red. Pedro Borges. Vol. 2. Madrid: Biblioteca de Autores Cristianos, 1992. 185-198.

Frankowska, Maria. „Symbolika religijna i jej znaczenie w wierzeniach Indian Meksyku na przykładzie znaku krzyża (wiek XVI-XX).” Etnografia Polska 29.2 (1985): 83-105.

Galmés, Lorenzo. Grandes evangelizadores americanos, Historia de la Iglesia en Hispanoamérica y Filipinas (siglos $X V$-XIX). Red. Pedro Borges. Vol. 1. Madrid: Biblioteca de Autores Cristianos, 1992. 615-630.

García y García, Antonio. Las asambleas jerárquicas, Historia de la Iglesia en Hispanoamérica y Filipinas (siglos XV-XIX). Red. Pedro Borges. Vol. 1. Madrid: Biblioteca de Autores Cristianos, 1992. 175-192.

Gómez Canedo, Lino. Evangelización, cultura y promoción social. Ensayos y estudios críticos sobre la contribución franciscana a los orígenes cristianos de México (siglos XVI-XVIII). México: Editorial Porrúa, 1993.

Grzybowski, Stanisław. Narodziny Świata Nowożytnego 1453-1605. Wielka Historia Świata. T. 6. Warszawa: Świat Książki, 2005.

Gutiérrez Casillas J. La organización de la Iglesia en la Nueva España, Historia general de la Iglesia en América Latina: México. Red. Enrique Dussel. Vol. 5. Salamanca: Ediciones Sígueme, 1984. 55-93.

Martín Rivera de J. La vida cotidiana de la cristiandad en la Nueva España, Historia general de la Iglesia en América Latina: México. Red. Enrique Dussel. Vol. 5. Salamanca: Ediciones Sígueme, 1984. 95-164.

Martínez Ferrer L. Otras recepciones de Trento en América (1585-1682), „Las asambleas eclesiásticas anteriores a la recepción de Trento.” Teología en América Latina. Red. Josep Ignasi Saranyana. Vol. 1. Madrid: Iberoamerica, Frankfurt am Main: Vervuert 1999. 181-219.

Martínez Ferrer, Luís. Alejos-Grau, Carmen José. „Las asambleas eclesiásticas anteriores a la recepción de Trento.” Teología en América Latina. Red. Josep Ignasi Saranyana. Vol. 1. Madrid: Iberoamerica, Frankfurt am Main: Vervuert 1999. 88-148.

Medina, Miguel Ángel. „Métodos y medios de evangelización de los Dominicos en América.” Actas del I Congreso Internacional sobre los Dominicos y el Nuevo Mundo. Sevilla: 21-25 de abril de 1987. Madrid 1988. 157-207.

Medina, Miguel Ángel. Los dominicos en América. Presencia y actuación de los dominicos en la América colonial española de los siglos XVI-XIX. Madrid: Editorial Mapfre, 1992.

Mendieta, Gerónimo de. Historia Eclesiástica Indiana. México: Editorial Porrúa, 1993.

Milhou, Alain. „Lateinamerika.” Die Geschichte des Christentums. Die Zeit der Konfessionen (1530-1620/30). Red. Marc Venard. Vol. 8. Freiburg im Breisgau: Herder 1992. 772-874.

Morales Valerio, Francisco. „La evangelización fundante (siglo XVI).” Historia de la Iglesia en Hispanoamérica y Filipinas (siglos XV-XIX). Red. Pedro Borges. Vol. 2. Madrid: Biblioteca de Autores Cristianos, 1992. 125-144.

Morales Valerio, Francisco. „La Iglesia en Yucatán.” Historia de la Iglesia en Hispanoamérica y Filipinas (siglos $X V$-XIX). Red. Pedro Borges. Vol. 2. Madrid: Biblioteca de Autores Cristianos, 1992. 199-214. 
Morales Valerio, Francisco. „México: la evangelización del noroeste.” Historia de la Iglesia en Hispanoamérica y Filipinas (siglos XV-XIX). Red. Pedro Borges. Vol. 2. Madrid: Biblioteca de Autores Cristianos, 1992. 166-168.

Morales Valerio, Francisco. „México: La Iglesia diocesana (I).” Historia de la Iglesia en Hispanoamérica y Filipinas (siglos XV-XIX). Red. Pedro Borges. Vol. 2. Madrid: Biblioteca de Autores Cristianos, 1992. 91-109.

Morales Valerio, Francisco. „México: La Iglesia diocesana (II).” Historia de la Iglesia en Hispanoamérica y Filipinas (siglos XV-XIX). Red. Pedro Borges. Vol. 2. Madrid: Biblioteca de Autores Cristianos, 1992. 116-121.

Nowa historia Meksyku. Tłum. Sarah Kuźmicz. Red. Erik Velásquez García. Warszawa: PWN, 2016.

Pérez Puente L. El concierto imposible. Los concilios provinciales en la disputa por las parroquias indígenas (México, 1555-1647), México: Iisue, 2016.

Ricard, Ricardo. La conquista espiritual de México, México: Editorial Jus, 2004.

Sahagún, Bernardino de. Rzecz z dziejów Nowej Hiszpanii, Księgi I, II, III. Kęty: Biblioteka Klasyków Antropologii, 2007.

Sanchez Herrero, José. „Catequesis franciscana en el s. XVII. Catecismos y doctrinas cristianas.” Actas del III Congreso Internacional sobre los Franciscanos en el Nuevo Mundo (siglo XVII) La Rábida, 18-23 de septiembre de 1989. Madrid: Editorial Deimos, 1989. 381-430.

Santos Hernández, Ángel. Los jesuitas en América, Madrid: Editorial Mapfre 1992.

Saranyana, Josep Ignasi. Alejos-Grau, Carmen Joesé. „La primera recepción de Trento en América (1565-1582)." Teología en América Latina. Red. Josep Ignasi Saranyana. Vol. 1. Madrid: Iberoamerica, Frankfurt am Main: Vervuert 1999. 131-148.

Saranyana, Josep Ignasi. Antonaya, María Luisa. „La teología académica en México, Teología en América Latina.” Red. Josep Ignasi Saranyana. Vol. 1. Madrid: Iberoamerica, Frankfurt am Main: Vervuert 1999. 283-367.

Synowiec, Ola. Dzieci szóstego stońca. W co wierzy Meksyk. Wołowiec: Wydawnictwo Czarne, 2018.

Szyszka, Tomasz. Listy różne ku chwalebnej ciekawości i chrześcijańskiemu zbudowaniu stużące, jezuickich misjonarzy z Ameryki Hiszpańskiej. Poznań: UAM, 2015.

Val, José María Alonso del. „Al estilo de Francisco. En la primera evangelización de América”. ITVR [Instituto Teológico de Vida Religiosa], Gracia y desgracia de la evangelización de América. Madrid: Publicaciones Claretianas, 1992. 229-282.

Tomasz Szyszka SVD, ks. dr hab. prof. UKSW, adiunkt w Katedrze Misjologii Instytutu Nauk Teologicznych WT UKSW. Zajmuje się historią ewangelizacji Ameryki Łacińskiej oraz badaniami nad pielgrzymkami Jana Pawła II do Ameryki Łacińskiej. 